\title{
The Use of Radiocarbon Dating of Organic Matter in the Study of Soil Genesis ${ }^{1}$
}

\author{
Y. A. Martel and E. A. Paul ${ }^{2}$
}

\section{ABSTRACT}

Radiocarbon dating was used to study the nature and the stability of the organic matter in a range of Chernozemic soils (Borolls) from Saskatchewan. Two catenas, one cultivated, the other not, were studied in detail; the bottom soils of the uncultivated catena contained buried horizons.

From the crest of the knoll to the depression, the mean residence time of the surface horizon of the cultivated catena decreased from 545 years before present (B.P.) to modern, the organic matter content increased and the percentage of hydrolyzable carbon decreased. The content of organic matter decreased but the mean residence time increased by 700 to 4,000 years in the $B$ horizons. Two buried horizons located at different depths underneath the lower members of the uncultivated catena showed mean residence times of 5,950 and 8,410 years B.P. indicating that mass movement of soil had periodically occurred since the last glaciation.

The ${ }^{14} \mathrm{C}$ content of a field soil, measured by radiocarbon dating, was compared with the ${ }^{14} \mathrm{C}$ distribution in fractions of another sample of the same soil after amendment with ${ }^{14} \mathrm{C}$ acetate and 350 days incubation in the laboratory. The artificially labelled soil accumulated more of the tracer in the acid hydrolyzable fractions than was found by radiocarbon dating the field soil. In turn, the distribution of soil nitrogen was more closely associated with the ${ }^{14} \mathrm{C}$ than with the unlabelled carbon of the soil.

Additional Index Words: humus, catena, mean residence time.

$\mathbf{R}^{\prime}$ ADIOCARBON DATING, utilizing naturally occurring ${ }^{14} \mathrm{C}$, has been used in soil work since 1950 , and measurements on buried soil as well as an organic relics found adjacent to the solum have been studied relative to the chronologic problems of soil genesis (4). The organic matter of most surface soils has been found to be sufficiently old to

${ }^{1}$ The results are part of Ph.D. dissertation by the first author, Univ. of Saskatchewan, Saskatoon, January 1972. A part of this work was presented in Div. S-3, Soil Science Society of America, Miami Beach, Florida, October 1972. Published as Sask. Institute of Pedology No. R116. Received 4 June 1973. Approved 4 Jan. 1974

${ }^{2}$ Graduate Student and Professor of Soil Science, respectively, University of Saskatchewan, Saskatoon, Canada. The senior author is now a Research Soil Scientist at the Canada Dept. of Agr., Ste-Foy, Quebec, Canada. yield usable radiocarbon measurements $(6,12,17)$. Most soil profiles show increasing radiocarbon dates with depth (18), and radiocarbon dating of soil organic matter extracts has provided information on the time sequence of their formation $(2,12,18)$. Although this technique has been the subject of recent reviews $(15,16,19)$, data are needed to relate radiocarbon dates with information on pedogenic factors such as those responsible for the formation of a catena.

Tracer techniques utilizing ${ }^{14} \mathrm{C}$ have made possible the study of the relative stability of different humic fractions of soil organic matter labelled with ${ }^{14} \mathrm{C}$ during incubation experiments. Paul (11) assembled data from a number of incubation experiments with ${ }^{14} \mathrm{C}$-labelled materials and concluded that the traditional fractions (humic acid, fulvic acid, and humin) showed a rather uniform distribution of the labelled carbon. Work with acid hydrolysis has been more successful in obtaining fractions of different specific activities (13). Radiocarbon dating gives an opportunity to study the distribution of naturally occurring ${ }^{14} \mathrm{C}$ in soils and to compare it with the results of experiments where labelled ${ }^{14} \mathrm{C}$-material was added to soil incubated in the laboratory.

The study was undertaken: (i) to investigate the variation in the stability and the characteristics of the soil organic matter as affected by the position on the slopes of a catena, by the depth in the profiles and by the burial of old soils and (ii) to investigate the distribution of naturally occurring ${ }^{14} \mathrm{C}$ in the fractions of soil organic matter in comparison with the distribution of ${ }^{14} \mathrm{C}$-labelled material added to the soil in the laboratory. This made it possible to test the hypothesis that successive hydrolysis of the soil organic matter provides meaningful information about its stability in nature.

\section{MATERIALS AND METHODS}

\section{Characterization of Soils}

The soils at Site no. 1 were cultivated and located at Waldheim in the upper part of the Black Chernozemic (Udic Boroll) soil zone. The uncultivated soils at Site no. 2 were located in the same soil zone at Quinton, $219 \mathrm{~km}$ (130 miles) southeast of the first site. The soils of both sites contain about $25 \%$ clay and have been derived from the same calcareous glacial till and 
under the same climate. The two catenerary sequences, classified as Oxbow, have the sequence of Rego, Orthic, and Eluviated Chernozemic profiles and a Gleysolic profile.

On the upper slope, the shallow development of the soil is recognized as a Rego Chernozemic (Udorthentic Haploroll) profile. The better developed soil on the intermediate slope was described as an Orthic Chernozemic (Udic Haploboroll) profile. On the lower slopes, the effect of the runoff water leads to an Eluviated Chernozemic (Udic Argiboroll) profile. In the lowest topographic position, excess water accumulates and the wet and poorly drained soil is classified as an Eluviated Gleysol (Argic Cryaquoll). A Humic Eluviated Gleysol (Argic Cryaquoll) occurs where excess water remains in the profile all year preventing the decomposition of the organic matter and a Low Humic Eluviated Gleysol (Argic Cyraquoll) occurs where the water retreats occasionally, allowing some decomposition of organic matter to take place.

The soil of Site no. 3 was cultivated and located at Matador in the Brown Chernozemic (Aridic Boroll) zone; it contains about $70 \%$ clay and has developed on calcareous lacustrine deposits.

A bulk sample from each selected horizon (Table 1) was used for analysis. Identifiable plant materials in the soil samples were removed by repeated flotations with $0.01 \mathrm{~N} \mathrm{HCl}$ and handpicking under $20 \times$ magnification of a stereomicroscope. Soil carbonates were destroyed with $1 \mathrm{~N} \mathrm{HCl}$. Organic carbon was determined by a dry-combustion method (22) using a $50 \% \mathrm{KI}$ solution to absorb the $\mathrm{HCl}$ present in soil fractions. Total nitrogen was determined by the Kjeldahl method (1). Amounts of soil varying between 50 and $800 \mathrm{~g}$ were necessary to obtain $3 \mathrm{~g}$ of $\mathrm{C}$ for radiocarbon dating.

\section{Fractionation of Soil Organic Matter}

The light materials were obtained after a densimetric fractionation (10) using $\mathrm{ZnBr}_{2}$ with a density of $2.0 \mathrm{~g} / \mathrm{cm}^{3}$ (Fig. 1). A portion of the organic matter remaining after flotation was extracted by successive $0.5 \mathrm{~N}$ and $6 \mathrm{~N} \mathrm{HCl}$ hydrolysis (13). The $\mathrm{NaOH}$ extraction, after acid hydrolyses, was basically the method of Tyurin (7). The residue of the $\mathrm{NaOH}$ extraction was treated with water and yielded a water extract and a residue called humin.

\section{Radiocarbon Dating}

The mean residence time (MRT) and the $\delta^{14} \mathrm{C}$ were calculated by using the equations

$$
\mathrm{MRT}=18,500 \log _{10}(A O / A)
$$

and

$$
\delta^{14} \mathrm{C}=[(A-A o) / A o] \times 1.000
$$

where $A O$, the activity of the modern standard, was based on $95 \%$ of the activity of NBS oxalic acid, and $A$ was the activity of the unknown sample (8). The mean residence time was expressed as years before present (B.P.) i.e. before 1950, and the ${ }^{14} \mathrm{C} C$ was expressed in per mil $\left({ }^{\circ} / \mathrm{Oo}\right)$. The value of 5,570 years was utilized as the half life of ${ }^{14} \mathrm{C}$.

\section{Discrimination Against ${ }^{14} \mathrm{C}$}

The discrimination against ${ }^{14} \mathrm{C}$ during photosynthesis and the subsequent biological transformations was determnied by measuring the ${ }^{13} \mathrm{C}$ value of samples relative to the NBS Solenhofen standard no. 20 such that

$$
\delta^{13} \mathrm{C}=\frac{{ }^{13} \mathrm{C} /{ }^{12} \mathrm{C} \text { sample }-{ }^{13} \mathrm{C} /{ }^{12} \mathrm{C} \text { standard }}{{ }^{13} \mathrm{C} /{ }^{12} \mathrm{C} \text { standard }} \times 1,000[3]
$$

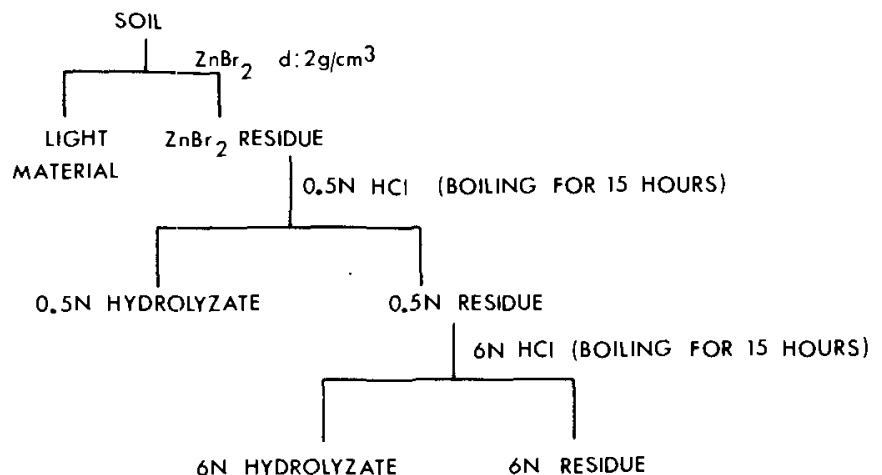

ON HYDROLYZATE
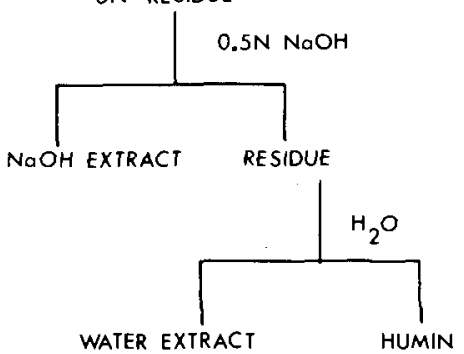

Fig. 1-Fractionation scheme utilizing acid hydrolysis.

The $\delta^{13} \mathrm{C}$ value was expressed in per mil $(\% / 0)$ and the mass spectrometer employed was an Atlas GD 150 (9).

\section{Incubation Experiment}

Sörensen and Paul (21) studied, in the laboratory, the transformation of acetate ${ }^{14} \mathrm{C}(100 \mu \mathrm{c} / \mathrm{g})$ into carbohydrate and amino acid metabolites during decomposition. They used a 0 to $15 \mathrm{~cm}$ depth sample of virgin Chernozemic soil (Aridic Boroll) and removed most of the roots by passing the soil through a $2 \mathrm{~mm}$ sieve. Incubation was continued for 350 days after which period a subsample containing $2.1 \%$ carbon was fractioned. The ${ }^{14} \mathrm{C}$ present in the fractions was absorbed in $\mathrm{NaOH}$ after dry combustion. It was then counted in a scintillation counter (23).

\section{RESULTS AND DISCUSSION}

The radiocarbon dating of the cultivated Black Chernozemic Ap horizons (Site 1) showed that the slope position of the organic matter in a catena affects the mean residence time (Table 1). The dating of the Ap horizon on the upper slope yeilded the oldest surface mean residence time of 575 years B.P. The mean residence times decreased on the slope to 270 years B.P. and 216 years B.P. In the depression, where the runoff water and its debris accumulated and where wet conditions were present, the mean residence time was modern. The decrease of the mean residence time from the intermediate slope toward the depression is associated with an increase in the amount of organic matter in the profile and a decrease in the percentage of hydrolyzable carbon. This shows that the amount, the nature, and the stability of the organic matter are affected by the position on the slope of the catena.

The mean residence times of two Ah horizons of the virgin Black Chernozemic soils (Site 2) were modern. These modern values may be attributed to the presence of a great amount of young material in the soil. The $0.01 \mathrm{~N}$ $\mathrm{HCl}$ flotation of the soil removed most of the undecom- 
Table 1-Mean residence times and characteristics of the organic matter sampled on Site 1 and Site 2

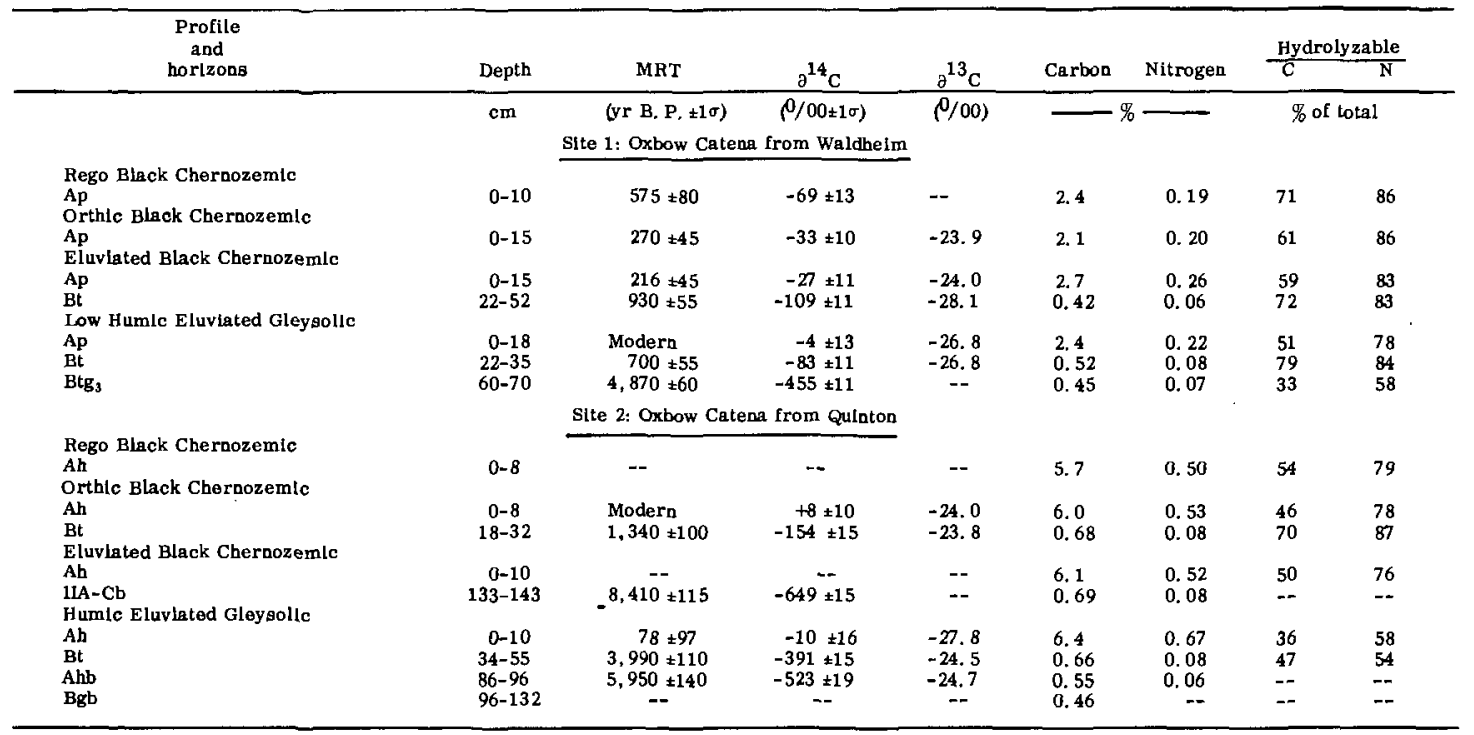

posed materials, but visual observation under the $20 \times$ stereomicroscope showed the presence of black particles likely comprised of partially decomposed materials that were not removed by the flotation. This partially decomposed material lying on the surface of the soil is not in close contact with the microorganisms, and it may remain in that form until it is washed down the profile by rain water or mechanically buried by soil animals. This material would lower the mean residence of the total soil organic matter from values already low (270 years in the case of the orthic profile of Site 1) to values lower than 100 years B.P. and therefore too young for radiocarbon dating. The effect of undecomposed materials is especially strong because of the high levels of bomb-produced ${ }^{14} \mathrm{C}$ in growing plants and recent residues. On Site 1 plowing likely accelerated the rate of decomposition of the newly added materials by mechanically bringing the organic matter of the surface soil in contact with the bulk of the microorganisms. For this reason, an Ah horizon would normally date younger than a corresponding Ap horizon.

The nature of the stability of the organic matter varied with the increasing depth. The mean residence times of the B horizons were all over 700 years B.P. The percentage of nonhydrolyzable carbon was smaller than in the $\mathbf{A}$ horizons with little change in the hydrolyzability of the nitrogen. This suggests, in agreement with the soil genesis concepts for those soils, that the nonhydrolyzable materials of the B horizons likely were formed in situ rather than being the result of a movement of the nonhydrolyzable material from the $\mathrm{A}$ horizons. The mean residence times of the organic matter present in the four $\mathrm{Bt}$ and the $\mathrm{Btg}_{3}$ horizons of Table 1 were correlated with the percentage of nonhydrolyzable carbon $\left(r=0.99^{* *}\right)$ and of the nonhydrolyzable nitrogen $\left(r=0.95^{* *}\right)$. Although these calculations are based only on five results, the high correlation values suggest that the chemical nature of the nonhydrolyzable material contributes to increased stability of the soil organic matter in these lower horizons.
Two prominent darker layers occurred at the 86 to 96 $\mathrm{cm}$ depth of the Gleysolic profile and at the 133 to $143 \mathrm{~cm}$ depth of the Eluviated Chernozemic profile of Site 2 (Table 1). The material found at $86 \mathrm{~cm}$ dated 5,950 years B.P. and at $133 \mathrm{~cm}$ dated 8,410 years B.P. The high mean residence time obtained from radiocarbon dating, therefore, suggest the presence of two old buried horizons. This, also, is supported by the relatively high carbon content $0.69 \%$ of the material found at $133 \mathrm{~cm}$. The mean residence time of a buried soil is a minimum estimation of the time since burial because the soil may be greater than zero at the time of burial and/or decomposition of recently added materials may continue after burial as long as the moisture and aeration conditions are not severely affected. One may, therefore, speculate that 8,410 years, the mean residence time of the deepest buried horizon, is the minimum time elapsed since an old land surface was covered by a layer of sediments presumably coming from the upper slope of that time. The profile characterized by an Ahb and a Bgb was buried at least 5,950 years ago by material forming today's surface.

The organic matter of the Ap 0 to $10 \mathrm{~cm}$ depth of the Brown Chernozemic soil (Site 3) which contained 1.9\% of carbon and $0.20 \%$ of nitrogen was fractioned (Table 2). Each fraction was radiocarbon dated except the light material which was too young for proper counting and the $0.5 N$ and the $6 N$ hydrolyzates which demanded too long a manipulation for accumulating the necessary $3 \mathrm{~g}$ of carbon. However, Paul et al. (12) showed that the mean residence time of such fractions could be calculated by difference, if the carbon content and the activity of the ${ }^{14} \mathrm{C}$ of the other fractions and of the total soil are known. By assembling the fractions in three groups comprised of (i) total soil, light material, and $\mathrm{ZnBr}_{2}$ residue, (ii) total soil, $0.5 \mathrm{~N}$ hydrolyzate, and $0.5 \mathrm{~N}$ residue, and (iii) total soil, $6 \mathrm{~N}$ hydrolyzate, and $6 N$ residue, one can calculate the unknown ${ }^{14} \mathrm{C}$ activity $\left({ }^{14} \mathrm{C}\right)$ of the nonradiocarbon dated fractions by using the equation 
Table 2-Mean residence times and $\delta^{14} \mathrm{C}$ of the fractions of the Brown Chernozemic soil (Site 3) and distribution of total nitrogen, organic carbon and ${ }^{14} \mathrm{C}$ in the fractions as it occurs in nature and 350 days after the addition of labeled ${ }^{14} \mathrm{C}$-acetate

\begin{tabular}{|c|c|c|c|c|c|c|c|c|c|}
\hline & \multicolumn{6}{|c|}{ Radlocarbon dated soll Ap 0-10 $\mathrm{cm}^{*}$} & \multicolumn{3}{|c|}{ Incubated soll Ah 0-15 cm+ } \\
\hline & MRT & $\partial^{14} \mathrm{C}$ & $\mathbf{N}$ & $14 \mathrm{C}$ & Soll-C & $14 \mathrm{C} /$ Soll-C & $11 \mathrm{C}$ & Soll-C & $14 \mathrm{c} / \mathrm{Sodl}-\mathrm{C}$ \\
\hline & yr B.P. $\pm 1 \sigma$ & $\%=0 \pm 1 \sigma$ & \multicolumn{3}{|c|}{$\longrightarrow \%$ of total $\longrightarrow$} & \multicolumn{4}{|c|}{ 一男 of total $\longrightarrow$} \\
\hline $\begin{array}{l}\text { Total soll } \\
\text { Lght materlal } \\
\mathrm{ZnBr}_{2} \text { resldue } \\
0.5 \mathrm{~N} \text { hrdrolyzate } \\
\text { O. } 5 \mathrm{~N} \text { residue } \\
6 \mathrm{~N} \text { hydrolyzate } \\
\text { 6N residue } \\
\text { NaOH ext ract } \\
\text { Water extract } \\
\text { Humin }\end{array}$ & $\begin{array}{c}350 \pm 65 \\
\text { Modern } \\
505 \pm 105 \\
\text { Modern } \\
855 \pm 70 \\
\text { Modern } \\
1,765 \pm 65 \\
1,910 \pm 105 \\
1,790 \pm 120 \\
1,330 \pm 100 \\
\end{array}$ & $\begin{aligned} &-43 \pm 9 \\
&+243 \pm 18 \ddagger \\
&-61 \pm 16 \\
&+7 \pm 15 \\
&-101 \pm 15 \\
&+61 \pm 22 \\
&-197 \pm 16 \\
&-212 \pm 16 \\
&-200 \pm 15 \\
&-153 \pm 17 \\
&\end{aligned}$ & $\begin{array}{c}100 \\
3.0 \\
97 \\
41 \\
56 \\
43 \\
13 \\
9.0 \\
1.5 \\
2.5 \\
\end{array}$ & $\begin{array}{l}100 \\
8.0 \\
97 \\
37 \\
55 \\
24 \\
31 \\
22 \\
2.6 \\
6.4 \\
\end{array}$ & $\begin{array}{l}100 \\
6.0 \\
94 \\
35 \\
59 \\
22 \\
37 \\
27 \\
3.1 \\
6.9 \\
\end{array}$ & $\begin{array}{l}1.0 \\
0.3 \\
0.98 \\
1.1 \\
0.93 \\
1.2 \\
0.84 \\
0.82 \\
0.84 \\
0.93\end{array}$ & $\begin{array}{l}100 \\
5.0 \\
95 \\
49 \\
46 \\
21 \\
25 \\
16 \\
3.4 \\
5.6 \\
\end{array}$ & $\begin{array}{c}100 \\
5.0 \\
95 \\
35 \\
60 \\
20 \\
40 \\
23 \\
7.0 \\
10.0 \\
\end{array}$ & $\begin{array}{l}1.0 \\
1.0 \\
1.0 \\
1.4 \\
0.78 \\
1.1 \\
0.63 \\
0.70 \\
0.48 \\
0.56\end{array}$ \\
\hline
\end{tabular}

${ }^{14} \mathrm{C}$ (unknown fraction)

$$
=\frac{{ }^{14} \mathrm{C}(\text { soil })-\left[{ }^{14} \mathrm{C} \times \% \text { of total } \mathrm{C}(\text { known fraction) }]\right.}{\% \text { of total } \mathrm{C} \text { (unknown fraction) }}
$$

From this ${ }^{14} \mathrm{C}$, the mean residence time and the $\delta^{14} \mathrm{C}$ of the light material, the $0.5 N$, and of the $6 N$ hydrolyzates may be obtained by using Eq. [1] and [2].

The mean residence time was 350 years B.P. for the total soil but it varied from modern to 1,910 years B.P. for the fractions (Table 2). The youngest fraction of the soil was the light material with a $\delta^{14} \mathrm{C}$ of +243 ; its nature was not fully characterized but from the $C / N$ ratio of 17 and a visual observation under a microscope, it appeared to be comprised of partly decomposed plant materials. This fraction enriched with ${ }^{14} \mathrm{C}$, coming from nuclear tests that have taken place since 1950 , showed that contamination of the soil organic matter with nuclear ${ }^{14} \mathrm{C}$ existed even though $6 \%$ of the original carbon of the soil had been previously removed by the flotation of the original soil sample in $0.01 \mathrm{~N} \mathrm{HCl}$. This contamination is important since $6 \%$ of carbon with $\delta^{14} \mathrm{C}$ of $+243 \%$ oo would have the same effect on the mean residence time as $16 \%$ of carbon coming from prebomb plant material.

The $\delta^{14} \mathrm{C}$ values of the modern $0.5 \mathrm{~N}$ and $6 \mathrm{~N} \mathrm{HCl}$ hydrolyzates were low, $+7 \%$ oo and $+61 \%$ respectively, but their amount, totaling $57 \%$ of the total carbon, contributed to lower the mean residence time of the $6 \mathrm{~N}$ hydrolysis residue by 1,260 years-from 1,765 years for the $6 \mathrm{~N}$ residue to 505 years for the $\mathrm{ZnBr}_{2}$ residue. In turn, the mean residence times of the nonhydrolyzable fractions were high and ranged between 1,330 and 1,910 years B.P. This suggests that the $0.5 \mathrm{~N}$ and $6 \mathrm{~N} \mathrm{HCl}$ hydrolyses can separate the young and/or the older materials in soil.
The ${ }^{14} \mathrm{C}$ content of a field soil from Site 3 , measured by radiocarbon dating, was compared with the ${ }^{14} \mathrm{C}$ distribution in fractions of another sample of the same soil after amendment with ${ }^{14} \mathrm{C}$-acetate and 350 days incubation in the laboratory (Table 2). The laboratory labelled soil accumulated $70 \%$ of the ${ }^{14} \mathrm{C}$-substances in the hydrolyzable fractions compared with $61 \%$ for the radiocarbon dated soil. This difference in the ${ }^{14} \mathrm{C}$ distribution came from the substances dissolved by the $0.5 \mathrm{~N} \mathrm{HCl}$ hydrolysis which extracted $12 \%$ more ${ }^{14} \mathrm{C}$ from the incubated soil.

The correlation between the ${ }^{14} \mathrm{C}$ and the soil- $\mathrm{C}$ within each experiment and between the two experiments are all significant, showing a similarity in the distribution of the natural ${ }^{14} \mathrm{C}$, the artificial ${ }^{14} \mathrm{C}$ and the soil- $\mathrm{C}$ in the different fractions (Table 3). However, the $\delta^{14} \mathrm{C}$ values did not correlate as closely $(r=0.66)$ with the ${ }^{14} \mathrm{C} /$ soil-C ratios in the incubated soil as in the radiocarbon dated soil $(r=$ $\left.0.98^{* *}\right)$. This indicates that the ${ }^{14} \mathrm{C} /$ soil- $\mathrm{C}$ ratios of the incubated soil can not be used to determine the relative stability of each fraction. This lack of correlation likely originated from the different forms of ${ }^{14} \mathrm{C}$ materials added to the soil; the ${ }^{14} \mathrm{C}$-acetate, incorporated as microbial substrate, decomposed rapidly whereas plant material naturally added in the field underwent slow microbial degradation with a greater proportion of the materials going into the fractions with high mean residence times.

The distribution of nitrogen was more closely associated with the ${ }^{14} \mathrm{C}$ materials $\left(r=0.86^{*}\right)$ than with the distribution of soil carbon $(r=0.77)$ in the radiocarbon dated soil. Assuming that the distribution of nitrogen of the dated soil is applicable to the incubated experiment, one sees that the nitrogen was also in better correlation with the ${ }^{14} \mathrm{C}$ $\left(r=0.83^{*}\right)$ than with the soil carbon $(r=0.78)$. Simon-

Table 3-Correlation between the measurements made on the fractions of the radiocarbon dated soil and the incubated soil labelled with ${ }^{14} \mathrm{C}$-acetate $\nmid$

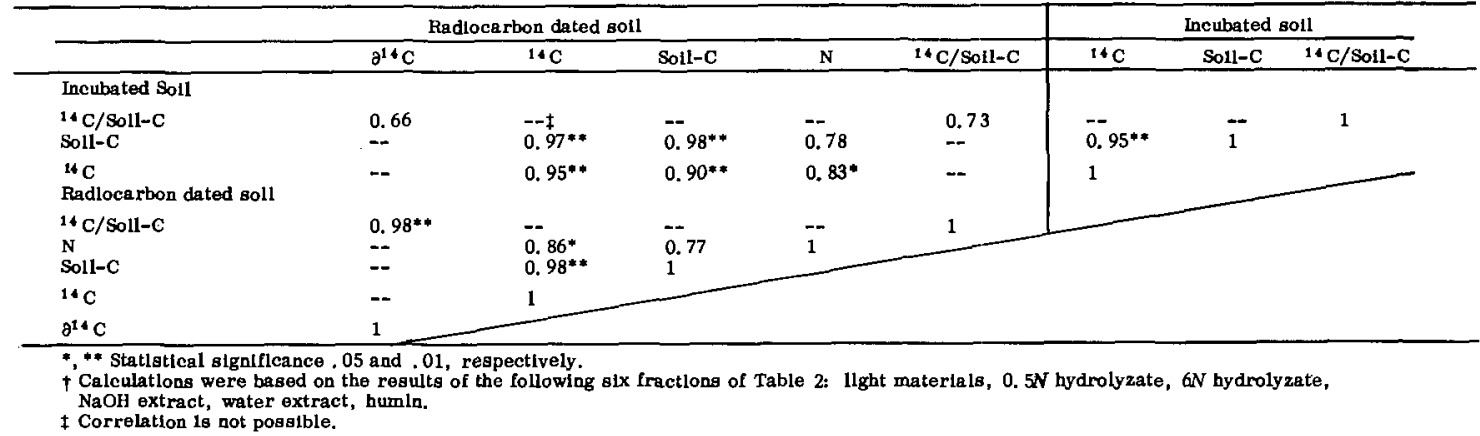


art and Mayaudon (20) have reported that when ${ }^{14} \mathrm{C}$-substrates such as glucose, hemicellulose, or cellulose decomposed in soils, the ${ }^{14} \mathrm{C}$ and the nitrogen were similarly distributed in the fractions. This suggests that, in studying the transformation of soil organic matter, the active fraction may be associated with nitrogen and can be analysed using ${ }^{15} \mathrm{~N}$, but the resistant material should be investigated with carbon by either radiocarbon dating or a ${ }^{14} \mathrm{C}$ isotope used in conjunction with long term field experiments.

The carbon isotopic composition of the soil organic matter can affect the mean residence time because the radiocarbon dating method was first standardized against pre1900 wood which had a $\delta^{13} \mathrm{C}$ of $-25^{\circ} \%$ oo relative to the University of Chicago PDB standard or $-23.9 \%$ oo with respect to the NBS Solenhofen standard which was used in this work (5). Samples with $\delta^{13} \mathrm{C}$ values that are not $-23.9 \%$ oo need correction for having an isotopic fractionation different from that of pre-1900 wood. The $\delta^{13} \mathrm{C}$ values of the total soil organic matter from samples of Site 1 and Site 2 varied between $-23.8 \%$ oo and $-28.1 \%$ (Table 1) and averaged $-25.4 \%$ oo. These are similar to the values reported by Campbell et al. (3) for other soils in Saskatchewan. The corrections of mean residence time for isotopic discrimination against ${ }^{14} \mathrm{C}$ are made possible by considering that the ${ }^{14} \mathrm{C} /{ }^{12} \mathrm{C}$ ratio is twice the ${ }^{13} \mathrm{C} /{ }^{12} \mathrm{C}$ ratio (14). The average $\delta^{13} \mathrm{C}$ value of $-25.4^{\circ}$ oo for soil organic matter indicates a discrimination of $3.0 \%$ oo against ${ }^{14} \mathrm{C}$ compared to the isotopic composition of pre- 1900 wood and leads to an error of +25 years for the radiocarbon measurement. This error is more than cancelled out by the decrease in mean residence time caused by the incorporation of plant materials containing ${ }^{14} \mathrm{C}$ derived from the atmospheric testing of thermonuclear weapons; consequently, it does not appear as an important factor in the radiocarbon dating of the soil organic matter used in this study.

\section{CONCLUSION}

The radiocarbon dating of organic matter of a catena verified the statement that the stability of organic matter is closely related to the pedogenic factors under which the soil is formed. The change of the mean residence time with position in the catena reflects the increased turnover of organic matter in the lower slope positions without a major alteration of the total organic matter content. It is not the purpose of this work to describe the dynamics of slope movement since too many parameters are involved, but the properties of the soil organic matter, as characterized by the radiocarbon measurements, the $\mathrm{C} / \mathrm{N}$ ratios and the hydrolysis of the total soil, show that important differences occurring along the slopes greatly affect the sampling requirements and the interpretation of soil organic matter investigations in soil genesis.

In these grassland soils, it appears that the organic matter of the A horizons normally turns over more rapidly than that of the Bt horizons where the physical effects of climate and animal mixing are greatly reduced. This is shown by a drastic change in the amount, the nature and the mean residence time of the organic matter between the $A$ and the $\mathrm{Bt}$ horizons. The decreasing $\mathrm{C} / \mathrm{N}$ ratios of the nonhydro- lyzable materials from $\mathrm{A}$ to the $\mathrm{Bt}$ horizons suggest that relatively more nitrogen is stored in the resistant nonproteinaceous forms in the $\mathrm{Bt}$ horizons than in the A horizons. Alternatively, other nonorganic forms of nitrogen resistant to hydrolysis would have to be retained in this fraction.

This work also has indicated that a great percentage of carbon and nitrogen in soil, containing a large amount of clay minerals, is biologically active in that it dates modern. The $0.5 N$ and $6 N$ acid hydrolysis dissolved the young organic constituents of the soil in both the naturally ${ }^{14} \mathrm{C}$ labelled field soil and under laboratory incubation where ${ }^{14} \mathrm{C}$ entered the soil organic matter as microbial residues. It is difficult to precisely define the structure of the humus from a dynamics standpoint, but the organic molecules that are not hydrolyzable certainly form a major portion of the resistant organic components in soil. These resistant components although active in that they affect soil physical and chemical properties play only a small role in the carbon cycle of these soils.

\section{ACKNOWLEDGMENT}

The senior author wishes to thank the National Research Council for the scholarship that made this study feasible. We are indebted to the Saskatchewan Research Council for providing facilities for radiocarbon dating work, and to Dr. D. A. Acton for assistance and guidance in soil sampling.

\section{LITERATURE CITED}

1. Bremner, J. M. 1965. Organic forms of nitrogen. In C. A. Black (ed.) Methods of soil analysis, Part 2. Agronomy 9:1238-1255. Amer. Soc. of Agron., Madison, Wis.

2. Campbell, C. A., E. A. Paul, D. A. Rennie, and K. J. McCallum. 1967a. Applicability of the carbon-dating method of analysis to soil humus studies. Soil Sci, 104: 217-224.

3. Campbell, C. A., E. A. Paul, D. A. Rennie, and K. J. McCallum. 1967b. Factors affecting the accuracy of the carbondating method of analysis to soil humus studies. Soil Sci. 104:81-84.

4. Gracanin, Z. 1971. Age and development of the Hummocky meadow (Buckelwiese) in the Lechtaler Alps (Austria). p. 117-127. In D. H. Yaalon (ed.) Paleopedologyorigin, nature and dating of paleosols. Int. Soc. of Soil Sci. and Israel Univ. Press, Jerusalem.

5. Craig, H. 1954. Carbon 13 in plants and the relationships between carbon 13 and carbon 14 variations in nature. J. Geol. 62:115-149.

6. Jenkinson, D. S. 1969. Radiocarbon dating of soil organic matter. Rep. Rothmansted Exp. Sta. for 1968. p. 73.

7. Kononova, M. M. 1966. Soil organic matter. Pergamon Press, London.

8. Martel, Y. 1971a. Radiocarbon measurements of the mean residence time of soil organic matter. p. 97-103. $\ln \mathrm{D}$. A. Rennie and E. A. Paul (eds.) Isotope methodology and techniques in soil-plant nutrition and plant physiology. Sask. Institute of Pedology, Saskatoon.

9. Martel, Y. 1971b. The use of the mass spectrometer for the measurement of ${ }^{13} \mathrm{C} /{ }^{12} \mathrm{C}$ ratios. p. $104-110$. $\ln \mathrm{D}$. A. Rennie and E. A. Paul (eds.) Isotope methodology and techniques in soil-plant nutrition and plant physiology. Sask. Institute of Pedology, Saskatoon.

10. Monnier, G., L. Turc, and C. Jeanson-Luusinang. 1962. Une méthode de fractionnement densimétric par centrifugation des matières organiques du sol. Ann. Agron. 13: 55-63.

11. Paul, E. A. 1970. Plant components and soil organic matter. Recent advan. phytochem. 3:59-104.

12. Paul, E. A., C. A. Campbell, D. A. Rennie, and K. J. McCallum. 1964. Investigations of the dynamics of soil 
humus utilizing carbon dating techniques. Int. Congr. Soil Sci. Trans. 8th 0:201-208.

13. Persson, J. 1967. A biological chemical study of soil organic matter fractionation. Int. Soc. Soil Sci., (Aberdeen) Trans. Comm. II-IV p. 59-64.

14. Rafter, T. A. 1955. Carbon-14 variations in nature and the effect on radiocarbon dating. N.Z. J. Sci. Technol. 37: 20-38.

15. Scharpenseel, H. W. 1971. Radiocarbon dating of soilsproblems, troubles, hopes. p. 77-96. In D. H. Yaalon (ed.) Paleopedology origin, nature and dating of paleosols. Int. Soc. of Soil Sci. and Israel Univ. Press, Jerusalem.

16. Scharpenseel, H. W. 1971. Special methods of chromatographic and radiometric analysis. p. 96-128. In D. A. McLaren and J. Skujins (eds.) Soil biochemistry. Vol. 2 Marcel Dekker Inc., New York.

17. Scharpenseel, H. W., F. Pietig, and M. A. Tamers. 1969. University of Bonn radiocarbon measurements II. Radiocarbon 11:3-9.

18. Scharpenseel, H. W., C. Ronzani, and F. Pietig. 1968.
Comparative age determination on different humic matter fractions. p. 67-73. In Isotopes and radiation in soil organic matter studies. Int. At. Energy Ag., Vienna.

19. Schnitzer, M., and S. V. Khan. 1972. Humic Substances in the environment. Marcel Dekker Inc., New York. p. $126-129$.

20. Simonart, P., and J. Mayaudon. 1966. Study of soil organic matter transformations with ${ }^{14} \mathrm{C}$. p. $245-257$. In The use of isotopes in soil organic matter studies. Rep. FAO/IAEA Tech. Meet. 1963. Brunswick-Volkenrode.

21. Sörensen, L. H., and E. A. Paul. 1971. Transformation of acetate carbon in carbohydrate and amino acids metabolites during decomposition in soil. Soil Biol. Biochem. 3: 173-180.

22. St-Arnaud, R. J. 1956. Manual of laboratory methods. Dept. Soil Science, Univ. of Saskatchewan, Saskatoon.

23. Warembourg, F. 1971. Studies of carbon transfer rates within the plant-soil system. p. 81-91. In D. A. Rennie and E. A. Paul (eds.) Isotope methodology and techniques in soil-plant nutrition and plant physiology. Sask. Institute of Pedology, Saskatoon. 